\title{
Bioclimatic Analysis State School in the City of Macapá-Amapá/Brazil
}

\author{
Jânio de Aragão \\ Architect at Eletrobrás / Brazil; \\ e-mail: janio.aragao@eln.gov.br \\ Adailson Bartolomeu \\ Professor at CEAP/Amapá/Brazil; \\ e-mail: adailsonb@yahoo.com.br

\section{Lissandro Botelho} \\ Professor at Federal Institute of Amazonas [Brazil], \\ PhD Student at Erasmus University Rotterdam [The Netherlands], and CNPq Fellow; \\ e-mail: lissandro.botelho@gmail.com \\ Alexander Lobo \\ Masters Student at Federal University of Pará; \\ e-mail: alex1606/r@yahoo.com.br
}

\section{Sylvio Mário Puga Ferreira}

Director at Social Sciences School / Federal University of Amazonas; sylviopuga@hotmail.com

\section{Luiz Agusto Soares}

Professor at Federal University of Amazonas, and PhD Student at Federal University of Minas Gerais; e-mail: las10@uol.com.br

\section{Doi:10.5901/mjss.2013.v4n11p621}

\section{Abstract}

The growth of cities shows the importance of seeking solutions that minimize the environmental impacts due to the fact that civil construction is among the activities that cause most environmental degradation. Bioclimatic architecture, that relates man to climate, optimizes the energy relations with the surrounding natural environment through architectural designs and particular strategies. The architectural design is the most adequate stage for implementing sustainability guidelines in the building. In the context of school building in the State of Amapá, the standard design developed by SEINF-AP asserts itself as a school building defined according to the construction rationalization for the generation of economy in public administration; however it has been found that due priority has not been given to the building environmental performance. The implantation of the building on the site and its physical configuration in the school environment should adapt itself to the climatic characteristics of the region and the terrain where it may be built. The lack of flexibility in these projects entails unfavorable conditions especially thermal comfort in the building - which interfere in productivity, motivation and concentration of the users.

Keywords: Bioclimatic architecture; standard school building, thermal comfort.

\section{Introduction}

The present Project considers the principles of bioclimatic architecture, the environmental factors, the human comfort and the architectural solutions in the constructed school environment.

Macapá, the Amapá state capitol, according to the 2012 Census Bureau data has a population of 415,554 , and is 
located in the extreme north of Brazil, on the banks of the Amazon River. The humid equatorial climate presents high temperatures, low wind velocity, high relative humidity rates and abundant precipitation with totals oscillating from 30 to $400 \mathrm{~mm}$ a month. In consequence, there is an increase in the annual average temperature, the record of which indicates approximately $27.1^{\circ} \mathrm{C}$. Therefore, one can see the importance of implementing strategies to obtain thermal comfort in the buildings because of these climatic characteristics.

In the Valeverde neighborhood we have the Professora Jacinta Carvalho State School, inaugurated on August 1st, 2012, with a 1200 student capacity, following the standard prototype of two stories with 16 classrooms, a multipurpose sports court, cafeteria, computer lab, auditorium and administrative block, according to the standard project established by the Amapá State Secretary of Infrastructure - SEINF. The building standardization has great advantages such as the speed of the public tender process, since the architectural, structural and complementary projects are defined, a specific tender is not necessary, allowing only the adjustments of implementing the building in the terrain. However, if the localization and solar orientation of the buildings is not taken into account, obeying the regional climatic characteristics, the quality of the school building may be affected, compromising the whole project. The result will be a project that may not meet the users' comfort requirements, that is, provide a favorable and stimulating educational environment. According to studies by Bartolomeu (2007), the fact that often the professionals who think constructed space do not take the behavior of the sun and the climatic conditions into consideration in the buildings and urbanization of equatorial cities causes the inhabitants to live with great thermal discomfort, be it in the buildings or in the open spaces (streets, squares and promenades). The inhabitants, meanwhile, try to solve this problem developing strategies to adapt to the local climate. However, the main focus of this project was based on the thermal comfort in school buildings, specifically with predetermined standard design, that is, whose architectural project is stipulated by modules based on the classrooms. Based on standardization, the spaces in a school building are organized in a determined plot taking into consideration only the current local legislation. In this context, the adaptation of the architectural project to the climate of a given region and the choice of materials befitting that climate are determinant factors to guarantee high quality architecture, entailing rationalized projects, reducing the energy consumption and offering satisfying thermal conditions to the user (BERALDO, 2007)

\section{Goal}

The goal of this project was to carry out a bioclimatic analysis of the school architecture currently used in the State of Amapá, where we intend to answer the following question: "does the implantation of standard school buildings adopted in the public school network in the state of Amapá allow a homogenous performance of the thermal comfort aspects for the users?"

\section{Method}

The Methodological procedures used in this project are based on the characterization of the E.E. Teacher Jacinta Carvalho, chosen as a case study, with data provided by the Amapá State Secretary of Infrastructure (SEINF), whose installations mention the project standard archetype and of the following analyses: the bioclimatic characteristics of the region under study with the use of the Climaticusprogram 4.1; of the ventilation in constructed environments with the use of the Fluxovento program; of the solar Incidence and shading of the diverse facades of the building in different periods of the year with the use of the Heliodon2 program. Through the result of these procedures we sought the definition of conclusive recommendations for the climate of the locality, as a form of contribution to education, research and practical applications, aiming to adjust to the normative requirement for thermal performance in the buildings.

\section{Climatic Characteristics of the Location}

Brazil has its climate mapped and divided into bioclimatic zones. These zones relate to the climatic characteristics of the various areas of the territory, which do not obey political mapping or division into States or economic regions. Based on these studies and its respective map, one can find the climate of each city, and correlate it through data that indicate the recommended strategies and bioclimatic construction guidelines for each site where a building will be designed and constructed. Studies of researchers related to the climates of diverse parts of the country mapped the Brazilian territory, dividing it into bioclimatic zones. As figure below, Amapá is in the Z8, its main recommendation being crossed ventilation, shade for openings and artificial refrigeration. According to Givoni diagram 27.1\% of the year Macapá presents 
characteristics of the Ventilation Zone. This situation occurs mainly in the middle of the night, from May through September. $72,9 \%$ of the year the city of Macapá is found in the Zone that requires artificial conditioning.
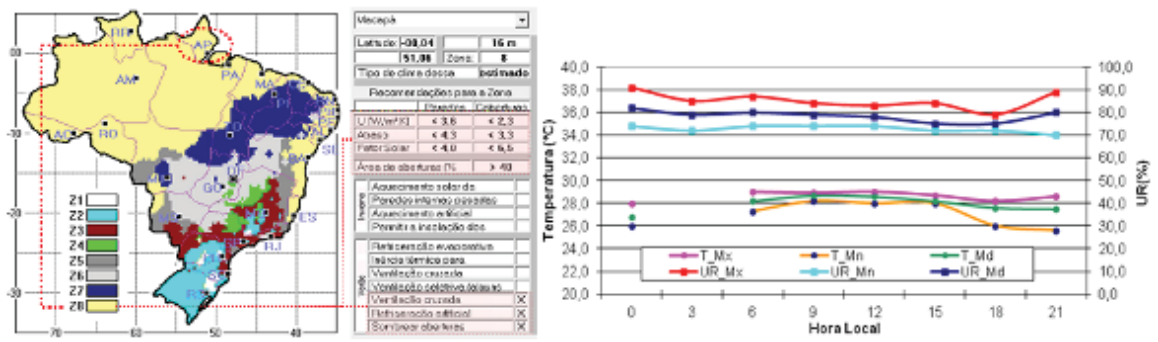

Figure 01 \& 02: On the left the map of climatic zoning in Brazil and recommended strategies, on the right, a graph with data on the temperature and relative humidity for Macapá (Adapted of ZBBR 1,1)

Macapá is found at the latitude $00^{\circ} 02^{\prime} 20 \mathrm{~N}$ and longitude $51^{\circ} 03$ ' $59^{\prime \prime} \mathrm{W}$. Its land area is 1,065, $00 \mathrm{~km}^{2}$. In this region, the global solar irradiation presents an annual average of $584,4 \mathrm{Wh} / \mathrm{m}^{2}$ day. Located in a tropical zone, the climate of the city it is classified as equatorial super-humid (hot and humid), a direct influence of the Amazonian forest due to its geographic localization (on the equator), with constant rains, small thermal amplitude and without defined climatic seasons, one observes throughout the period, that the average temperature, average maximum and minimum average of air were of the order of $26,8^{\circ} \mathrm{C}, 27,9^{\circ} \mathrm{C}$ and $25,7^{\circ} \mathrm{C}$, respectively. According to data of the Ministry of Agriculture Meteorology Service (1931/1960 norms), the greatest annual frequencies of the winds for the city of Macapá are northeast (29\%), north (10\%) and east (9\%). The frequency from other directions is insignificant. The average wind speed is between 2,6 and 2,9m/s and there is a lull $45 \%$ of the 12 months, as shown in figure 03 .

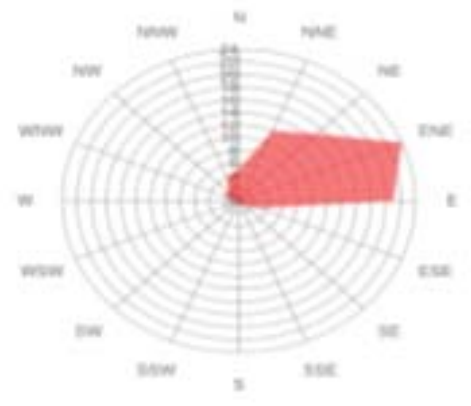

Figure 03: Statistical diagram of the winds in Macapá (site Windfinder)

\section{Standard School Building}

Standardized school construction system appeared in Brazil in the 70's (Kowaltowski, 2005). The idea was to project a unified standard so that it could be repeated on different terrains of different cities, modifying only the form of implantation. For the case study, the school building archetype of the Government of the State of the Amapá was analyzed. This standard was conceived in 2008 by the technical team at the State Secretary of Infrastructure - SEINF. Since then the new schools of the State of the Amapá have rigorously followed the archetype for public education buildings. The project presents a typology with classrooms directed in opposing directions, divided in four parts with hallways directed outwards. In this standard the blocks can be two or three floors with 8, 12 or 16 rooms. All of them have a library, auditorium, sports court, cafeteria, etc.

This archetype of school construction has an estimated cost of $R \$ 4.000 .000,00$ (four million Real ). Starting in 2008 the Amapá Government initiated the construction of four schools archetypes, being: Nanci Nina Costa (Macapá); Elesbão (Santana) State school and the Augusto of the Angels State School, currently being inaugurated, in Macapá. 

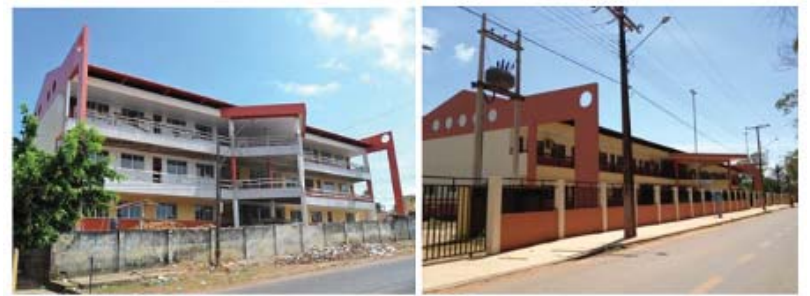

Image 01 \& 02: E.E. Augustus of the Angels on the left and E.E. Profa Jacinta on the right (Aragão, 2012).
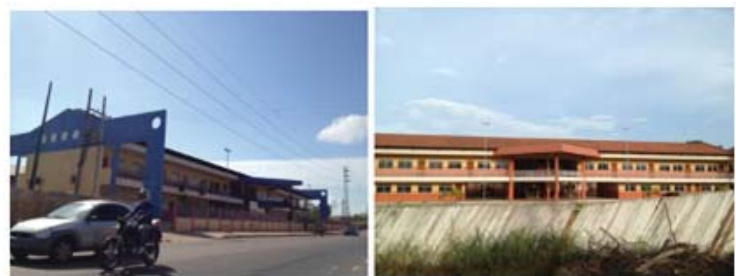

Image 03 \& 04: E.E. Profa Nanci Nina, on the left and E.E. Bairo Elesbão, on the right (Aragão, 2012).

The construction of a new school unit involves several stages, from the donation of the land by the city, through the process of implanting the standard project on the terrain, the approval of this project by the competent agencies, and the bidding process, and up to the actual construction.

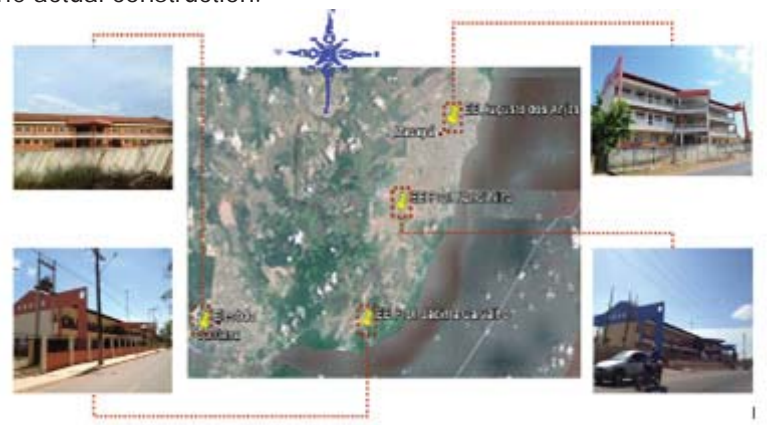

Figure 04: Map of Standard School locations

\section{Prof Jacinta Carvalho State School}

The Prof Jacinta Carvalho State school is situated in the Valeverde neighborhood in the city of Macapá, in the urban zone at $0^{\circ} 02^{\prime} \mathrm{S}$ and $51^{\circ} 06^{\prime} \mathrm{W}$, near the fazendinha district where the main watering-place of the city is located. The land made available for the school encompasses an area of $7900 \mathrm{~m}^{2}$, and is surrounded by native vegetation and a preservation area on the west, being accessible via the Marinha Street.

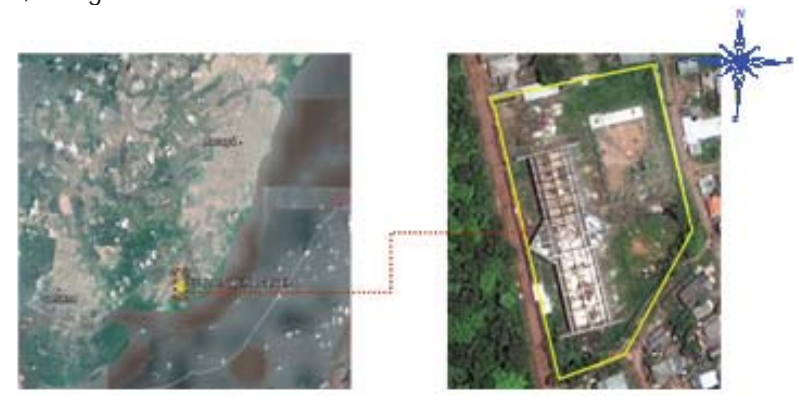

Figure 05: Aerial image of the school 
The executive project follows the Amapá State Government archetype proposal for school construction and is divided as follows: two floors with: 16 classrooms; computer lab; Auditorium; Library; Administrative area; Conference room; teachers' room; Educational nucleus; sports court; Cafeteria and Bathrooms. The project foresaw three blocks, the main block being rectangular, twelve meters wide by 80 meters long, the multi-sports court 24 meters wide by 45 meters long and the cafeteria 26 meters wide by 10 meters long. The present study detained itself to the main block.

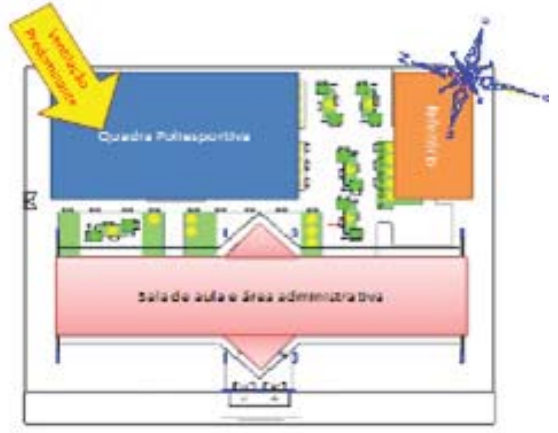

Figure 06: Implantation of the Jacinta Carvalho School

The building faces the east-northeast quadrant at 14 degrees to the west of due north. The facades will be called, for simplicity, east and west facade existing angle is minor.

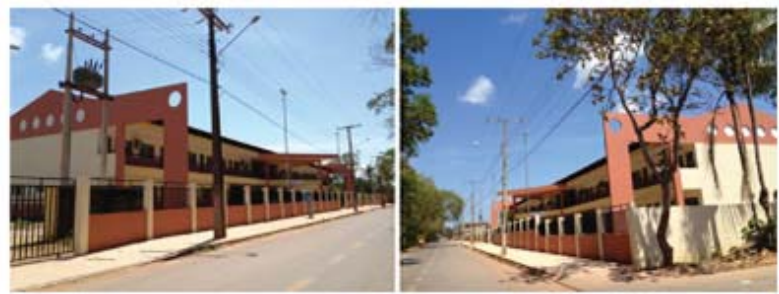

Image 05 \& 06: View of the Standard School from the Rua da Marinha (Aragão, 2012).

The main building is twelve meters wide by 80 meters long divided in two floors with ceilings $4 \mathrm{~m}$ high each. The 16 classrooms measure $6 \mathrm{~m}$ wide by $8 \mathrm{~m}$ long each, 8 rooms facing east and 8 facing west. There is a great hall dividing the two blocks of classrooms, where the stairs are placed. The classroom window frames are made of aluminum and glass $6 \mathrm{~mm}$ thick, with sills at $1,40 \mathrm{~m}$, and $2,40 \mathrm{~m}$ wide and $1,50 \mathrm{~m}$ high.

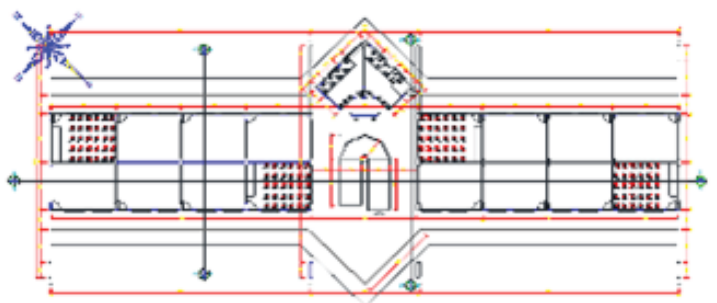

Figure 07: Upper floor blueprint

\section{Analysis with Bioclimatic Tools}

\subsection{Study of facade insulation}

The main façade faces west, which is unfavorable, since, as can be seen in figure 08 , the sun shines directly on the largest facade throughout the year heating the walls and consequently raising the temperature in internal environments. This directly influences the performance of the building. The north and south façades, the smallest of the building, are in a more favorable position, due to lesser incidence of solar radiation. This condition is fairly constant during the entire year 
and varies little in in the course of the day.

For the analysis of the intensity of the insolation on the façades Heliodon2 and Climaticus 4,1 software was used, as we can see in a simplified form: North Facade $=$ in the afternoon there is a solar incidence of $680 \mathrm{~W} / \mathrm{m}^{2}$; South façade $=$ in the morning there is a solar incidence of $650 \mathrm{~W} / \mathrm{m}^{2}$; East facade $=$ in the morning there is a solar incidence of 680 $\mathrm{W} / \mathrm{m}^{2}$; West facade $=$ in the afternoon there is a solar incidence of $680 \mathrm{~W} / \mathrm{m}^{2}$.

Still through Climaticus 4,1 data, it can be observed that the east, north and west facades receive solar incidence be it in the morning or the afternoon, and at all hours of this period and during the whole year. On the other hand for the south façade this condition changes, being more favorable for this facade, since one can see, for example, that in the month of June the sun only reaches this facade between 7 and 8 am.

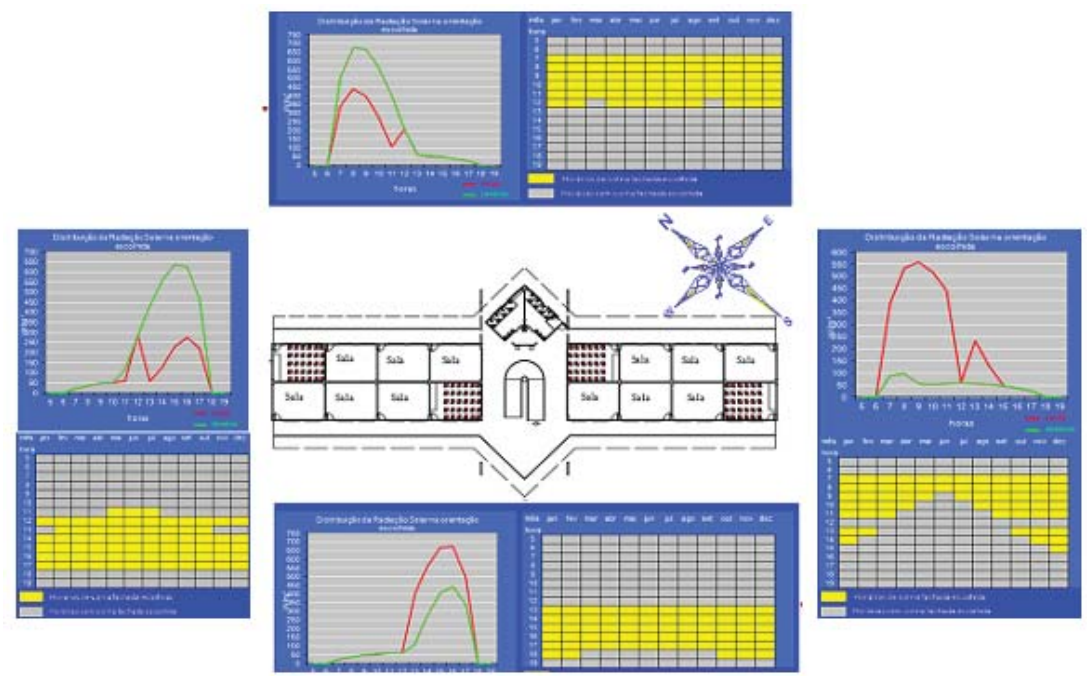

Figure 08: Diagram of insolation on the facades (Adapted from Climaticus 4,1).

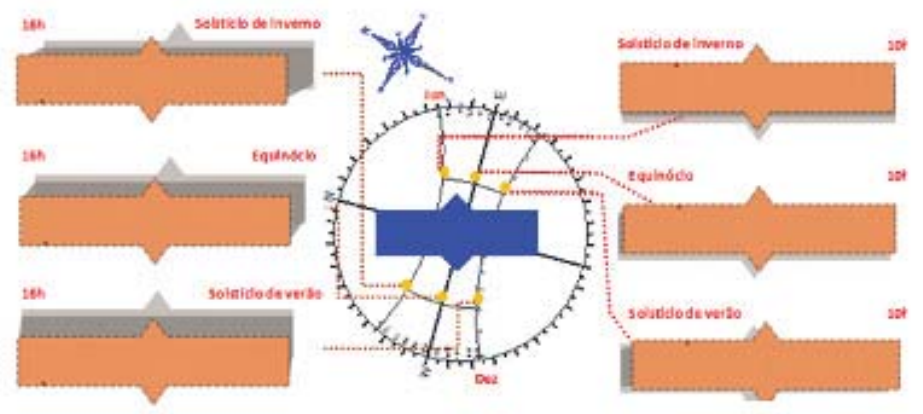

Figure 09: Analysis of the shading of the construction throughout the year (Adapted from Heliodon2)

The east facade at 10am suffers the greatest incidence of solar radiation and according to the analysis of the projected solar chart on the construction we see that the facade is not protected at this period. The sun impacts the facade without obstacle until 10am during every month of the year. From March to September the insolation occurs until 11am. The west facade at $4 \mathrm{pm}$ suffers the greatest incidence of solar radiation and according to the analysis of the projected solar chart for the building we see that this is the least favorable facade. There is no protection starting at $2 \mathrm{pm}$ throughout the year. The sun reaches this facade that even has large glass windows $6 \mathrm{~mm}$ thick that do not prevent the entrance of solar radiation. 

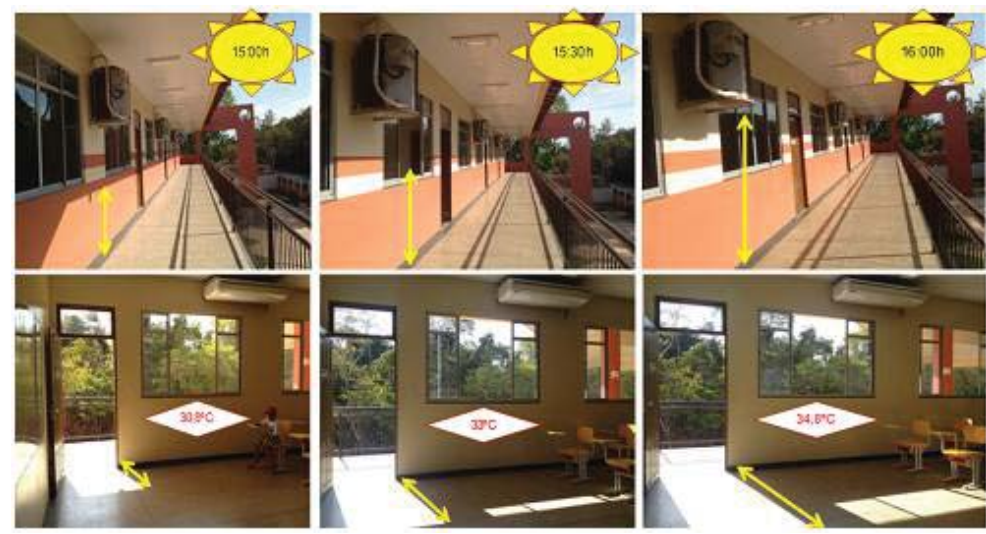

Image 07: Solar incidence on the west facade from 3pm to 4pm and penetration into the room (Aragão, 2012).

The conditions shown above demonstrate the solar incidence on the wall of the classroom, as well as the penetration of the sun into the classroom 3pm, 3:30pm and $4 \mathrm{pm}$. The sun invades the room starting at 3:30pm causing the temperature to rise. Even with the $2.5 \mathrm{~m}$ hallway and the $1.2 \mathrm{~m}$ eaves there is no barrier for the sun, allowing the same to shine on the wall of the classrooms facing west from $2 \mathrm{pm}$ until it sets. The lack of flexibility in the project archetype ensures that this situation is presents in the other schools as well.
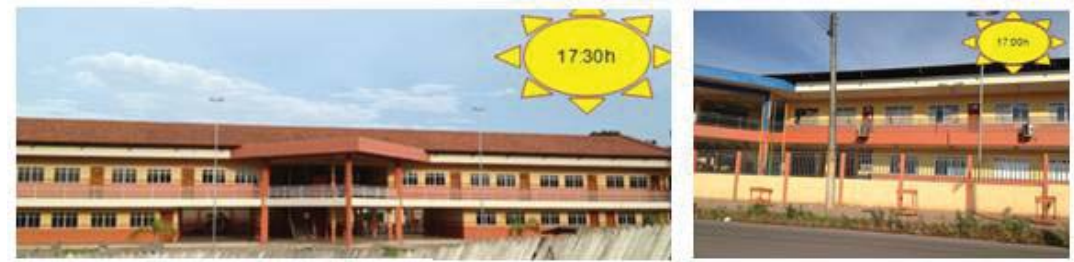

Image 08 \& 09: Solar incidence onthe main façade of the E.E. Profa. Nanci Nina (Aragão, 2012)

\subsection{Study of ventilation}

In relation to the ventilation, even if the construction directly faces the predominant ventilation, it does not possess crossed openings and consequently, according to simulations made using fluxovento software, the wind does not penetrate the classrooms and there is little ventilation in the hallway of the building. Analyzing only the room one perceives that the lack of openings opposite the existing windows, even with incidence of ventilation in the place, hinders penetration of the ventilation into the classrooms.

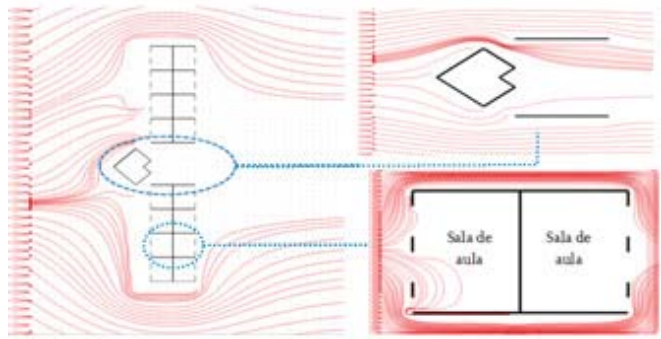

Figure 10: Wind flow in the building and classrooms (Adapted from Fluxovento) 


\subsection{Survey of the environmental restrictions}

Measurement of the climatic parameters during peak hours of solar incidence in the classrooms facing west and east in the table below:

\begin{tabular}{|c|c|c|c|c|c|c|}
\hline \multicolumn{7}{|c|}{ Classroom 9 - East } \\
\hline \multirow{2}{*}{ Parameter } & \multirow{2}{*}{ Unit } & \multicolumn{7}{|c|}{ 10am } \\
\cline { 3 - 7 } & & Point 1 & Point 2 & Point 3 & Point 4 & Point 5 \\
\hline Temperature & ${ }^{\circ} \mathrm{C}$ & 30 & 29.8 & 29.9 & 29.9 & 29.9 \\
\hline Relative humidity & $\%$ & 67 & 67 & 67 & 67 & 67 \\
\hline Noise & $\mathrm{dB}$ & 33.4 & 33.4 & 33.4 & 33.4 & 33.4 \\
\hline Lighting & Lux & 1060 & 666 & 227 & 218 & 490 \\
\hline Wind flow & $\mathrm{m} / \mathrm{s}$ & 0 & 0 & 0 & 0 & 0 \\
\hline
\end{tabular}

Table 1: Climatic parameters found in room 9

The values verified in the analysis of room 9, show the absence of wind flow in the classrooms due to the existing openings being all in the same wall, not allowing cross ventilation. The classrooms have good luminosity, presenting values above those recommended by NBR 5413 (in classrooms the luminosity must be over 200 Lux). The noise did not present variations even though the school is located on a public street, thus being susceptible to the noise from the same. The temperature registered below $30^{\circ} \mathrm{C}$ even at the peak of solar radiation (10am), at this time the east facades already do not suffer much solar incidence.

\begin{tabular}{|c|c|c|c|c|c|c|}
\hline \multicolumn{7}{|c|}{ Classroom 13 - West } \\
\hline \multirow{2}{*}{ Parameter } & \multirow{2}{*}{ Unit } & \multicolumn{7}{|c|}{ 4pm } \\
\cline { 3 - 7 } & & Point 1 & Point 2 & Point 3 & Point 4 & Point 5 \\
\hline Temperature & ${ }^{\circ} \mathrm{C}$ & 34.7 & 34.7 & 34.9 & 34.9 & 34.8 \\
\hline Relative humidity & $\%$ & 56 & 56 & 56 & 56 & 56 \\
\hline Noise & $\mathrm{dB}$ & 32.6 & 32.6 & 32.6 & 32.6 & 32.6 \\
\hline Luminosity & Lux & 712 & 435 & 1780 & 2478 & 846 \\
\hline Wind flow & $\mathrm{m} / \mathrm{s}$ & 0 & 0 & 0 & 0 & 0 \\
\hline
\end{tabular}

Table 2: Climatic parameters found in room 13

The values verified in the analysis of room 13, also show the absence of wind flow in the classrooms, good luminosity and the noise levels without variations, however the temperature showed itself very high, since at the peak of solar radiation (4pm), the west facades suffer high solar incidence. With the intention of going deeper in the analysis we checked the incidence of wind flow and temperature in the hallway that leads to the classrooms, which possess openings that allow cross ventilation and is shaded constantly, even in the hours of peak solar radiation. We found that the temperature of the hallway outside the classrooms held steady at $29.8^{\circ} \mathrm{C}$ during the whole afternoon and were able to perceive a wind flow of $1.2 \mathrm{~m} / \mathrm{s}$.

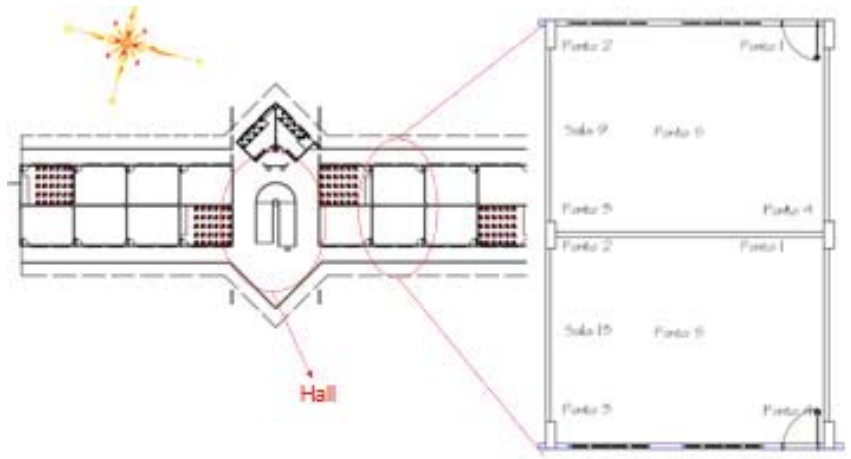

Figure 11: Map of the localization of the points where the parameters were collected 
Comparing the conditions of the Hallway with those in room 13, that receives direct insolation starting at 3:30pm, we saw a stability of temperature in the Hallway while in room 13 the temperature went up considerably, passing from $30.8^{\circ} \mathrm{C}$ to $34.8^{\circ} \mathrm{C}$, as seen in graph 01.

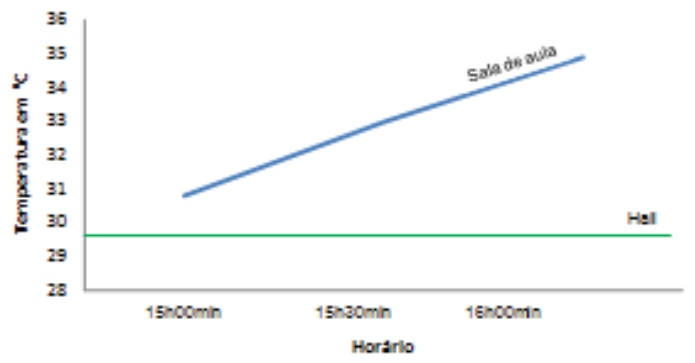

Graph 01: Evolution of the temperature on the West facade from 3pm to 4pm (Aragão, 2012).

\section{Final Considerações and Recommendations}

Knowledge of the climate and bioclimatic strategies shows itself as an important step to understanding the real necessity imposed by the environment and that it must be taken into consideration in the buildings. Through the climate analysis using the Givoni Diagram, it is observed that the city of Macapá, whose climatic characteristic, according to Koppen, are equatorial super humid (Af) this being the only type of incident climate in the State of the Amapá; only $0.3 \%$ of the year the city is in the zone of comfort and $72.9 \%$ requiring artificial conditioning, hence the great necessity to adapt the building to the climate. We can conclude, without rigorous analysis, that the solar orientation of the standard school building developed by the Amapá State government does not correspond to the ideal of ambient comfort recommended by the Brazilian Climatic Zoning. Even not being ideal, there was no concern in adapting the building to the consequent impact of the chosen orientation.

The temperature of the classrooms exposed to solar radiation, in the period of the afternoon in comparison with the covered and shaded hallway, where ventilation circulates at $1.2 \mathrm{~m} / \mathrm{s}$ on average, had considerable thermal gain. This demonstrates that ventilation and protection from the solar rays are primordial for the architectural project. The architectural recommendations for the Climatic Zone Z8, where Macapá is found, determine that the means buildings should use to minimize the effect of the climate are: cross ventilation, shade over openings, protection of the facades and artificial conditioning. It is highlighted that ample eaves, with the intention of horizontal protection of the facade, and opening in the cover to allow ventilation for cooling were two good examples of strategies adopted in the standard project.

To assuage the lack of thermal comfort in the school the solution adopted by the State Secretary of Education was the refrigeration of all the rooms, with installation of 48.000 BTUs central air conditioner in each room, what causes an increase in the consumption of electric energy, a solution that goes against sustainability actions. As did several other archetypes, the standard school building did not take characteristics of climate and location into consideration, thus being open to providing unfavorable aspects for the thermal performance of the construction, when implanted contrary to what would have been adequate for the local climate.

The standard school building adopted in the State of the Amapá, in the case study, does not cater to the aspects of livability and wellbeing in the school building, if it does not rigorous study standards of implantation and performance for the climate of the state of Amapá (Af). The bioclimatic architecture must be inserted in the context of the standardized constructions of the Amapá State Secretary of Infrastructure.

In implanting all the standard school buildings, the main streets where the lots are inserted have as their mains feature the facades facing west; however this facade is least favorable for the Macapá's climate. Therefore, since the lots allowed a more favorable orientation, apparently more importance was given to decorative architecture, in detriment to the performance of the building. Another aspect under analysis, of the cited classrooms, is the fact of the organization of the layout for teaching, the localization of the whiteboard, situated perpendicular to the direct solar incidence, interferes with the teacher's work.

To assuage the impact caused by the deficiency in the project we recommend the following improvements in the building: - Extend the existing horizontal protection for the facades east and west; - Create vertical protection such as brises-soleil, sun screens, marquees, decorative bricks with air passages, blinds for the east and west facades; - Create 
microclimate area for protection and to soften the temperature.

The main users of this environment are most affected, therefore they can suffer from attention deficit, decreased productivity and results in activities carried out. Being thus, the main objective, education, is jeopardized by the implanted physical structure.

To make available areas with better quality, economy and performance of the constructed space, taking into consideration the natural resources, is the main challenge of architecture. Through study and analysis of the problems of the existing standard project, we can see in practice the importance of the theoretical knowledge acquired academically and its consequences for the users. Therefore, the main goal of this analysis was reached and will serve as a basis for application in future projects.

\section{References}

Aragão, Jânio Jose Lima. Bioclimática analysis of the E.E. prof Jacinta Carvalho in the quarter valeverde in the city of Macapá. (TCC) In: CEAP, 2012, Macapá-AP.

Brazilian Association Of Technical Norms. Abnt Nbr 15215-3 Natural Illumination Part 3:

Bartolomeu. Oliveira. Ciudad there ecuatorial bioclimático Analisís en of Belém of Pará - Brazil. Barcelona, 2007. Tesina (postgrado) Polytechnical Universidad of Catalunya.

Beraldo, Juliano Coronato. Energy efficiency in buildings: evaluation of a proposal of regulation of thermal performance for the architecture of the state of São Paulo. 2006. $283 \mathrm{f}$.

Gonçalves, P. H. L.; Jesus, E. S.; Oliveira, M. C. F.; Coast, M. C.; Silva Júnior, J. .; Saints, L. . R. hídrica and thermal Availability for the city of macapá-AP, period of 1968-2000, UFPA/DM - 2002.

Kowaltowski, Doris Catharine Cornelie Knatz, FUNARI, Teresa B. Pertaining to school architecture and evaluation after-occupation. In: ENCAC - ELACAC, 2005, Maceió. p. 1-3.

http:> Had access in 03/12/2012.

\section{Script of video}

\begin{tabular}{|c|c|c|}
\hline$t(s)$ & Image & Sound \\
\hline 0 & Título & \multirow{4}{*}{ Música suave ao fundo: 01 - Turn (Travis) } \\
\hline 2" & Introdução & \\
\hline $16 "$ & Objetivos & \\
\hline $31 "$ & Metodologia & \\
\hline $52 "$ & Caracterização Climatica Do Lugar & \\
\hline 1'13" & Edificação Escolar Padrão & \\
\hline 1'34" & Escola Estadual Professora Jacinta Carvalho & Música suave ao fundo: 01 - Turn (Travis) \\
\hline 2'05" & Análise Com Ferramentas Bioclimáticas & \\
\hline 2'31" & Considerações Finais E Recomendações & \\
\hline 2'52" & Referencias Bibliográficas & \\
\hline
\end{tabular}

